\title{
PENGARUH LIKUIDITAS, PROFITABILITAS, DAN STRUKTUR ASET TERHADAP STRUKTUR MODAL PERUSAHAAN
}

\author{
Erni Kurniasari ${ }^{1}$, Listiawati $^{2}$ \\ Fakultas Ekonomi dan Bisnis, Universitas Bina Bangsa ${ }^{1,2}$ \\ kurniasarierni88@gmail.com, listy234@gmail.com
}

\begin{abstract}
This research aims to determine the influence of liquidity, profitability, and asset structure on capital structure partially and simultaneously. The population in this research are pharmaceuticals companies listed on the Indonesian Stock Exchange in the period 2015-2019. The sample selection used purposive sampling method. The sample in this research are 7 pharmaceuticals companies listed on the Indonesian Stock Exchange for 5 years in the period 2015-2019. Based on the results of this research, the researcher concludes that partially profitability and asset structure have a significant influence on the capital structure, while liquidity has no significant influence on the capital structure. Simultaneously, liquidity, profitability, and asset structure have a significant influence on the capital structure. The coefficient of determination is 0,517 , showed that liquidity, profitability, and asset structure have $51,7 \%$ to the capital structure, while $48,3 \%$ are determined by another variables.
\end{abstract}

Keywords: Capital Structure, Liquidity, Profitability, Asset Structure

\section{PENDAHULUAN}

Keputusan pengelolaan sumber dana dalam suatu entitas usaha atau bisnis akan terlihat dalam laporan keuangan yang berupa neraca. Keputusan pengelolaan modal yang baik apabila terjadi perimbangan antara modal asing dan modal sendiri atau modal yang berasal dari dalam perusahaan dan modal yang berasal dari luar perusahaan. Perimbangan antara modal sendiri dengan modal asing diistilahkan dengan struktur modal. Struktur modal menunjukan proporsi atas penggunaan utang untuk membiayai investasinya, sehingga dengan mengetahui struktur modal, investor dapat mengetahui keseimbangan antara risiko dan tingkat pengembalian investasinya. Konsep penting struktur modal adalah masalah sumber dana dan penggunaan dana. Dana dapat dipenuhi dari sumber intern ataupun sumber ekstern perusahaan. Dana tersebut dialokasikan untuk membelanjai aktiva perusahaan. Pemenuhan dan pengelolaan dana menyangkut keseimbangan finansial dalam perusahaan dimana hal tersebut dapat dicapai apabila perusahaan selama menjalankan fungsinya tidak menghadapi gangguan-gangguan finansial yang disebabkan tidak adanya keseimbangan antara jumlah modal yang tersedia dengan modal yang dibutuhkan (Sulindawati, Yuniarta, dan Purnamawati, 2020). Kebijaksanaan struktur modal merupakan pemilihan antara risiko dan pengembalian yang diharapkan. Terdapat struktur modal yang optimum atau paling tidak terletak dalam suatu rentang tertentu untuk suatu perusahaan, dan seberapa besar perusahaan menggunakan modal sendiri, tentu saja tergantung dari kondisi perusahaan yang bersangkutan. Sampai saat ini masih sulit untuk menentukan satu struktur modal yang optimal karena antara satu perusahaan dengan perusahaan lainnya yang berbeda kondisinya. Pemahaman konsep struktur modal membantu manajer keuangan untuk mengidentifikasi faktor utama struktur modal yang optimal, yang terkait dengan situasi dan kondisi perusahaan yang bersangkutan (Musthafa, 2017).

Rasio likuiditas mencerminkan kemampuan perusahaan dalam melunasi kewajiban jangka pendeknya, atau seberapa cepat perusahaan mengubah aset yang dimilikinya menjadi kas. Rasio ini menggambarkan risiko kredit jangka pendek sekaligus menggambarkan efisiensi 
penggunaan aset jangka pendek. Rasio likuiditas yang digunakan dalam penelitian ini adalah current ratio, dimana rasio ini untuk menghitung kemampuan perusahaan melunasi seluruh kewajiban jangka pendek yang menggunakan aset lancar yang dimiliki. Makin tinggi current ratio maka makin likuid kondisi keuangan perusahaan. Nilai rasio lebih dari satu menunjukkan kesehatan keuangan perusahaan yang baik karena jumlah aset lancar melebihi liabilitas lancar. Nilai current ratio yang tinggi menandakan likuiditas jangka pendek yang tinggi dan risiko kredit yang rendah karena perusahaan memiliki kemampuan yang lebih baik dalam hal melunasi kewajiban jangka pendeknya (Sukamulja, 2019). Semakin likuid kondisi keuangan perusahaan maka semakin baik struktur modal perusahaan, karena perusahaan menggunakan aset lancar untuk mendapatkan keuntungan yang besar. Penelitian yang dilakukan Mufidah, Ulupui, dan Prihatni (2018) menunjukkan bahwa likuiditas berpengaruh negatif signifikan terhadap struktur modal. Begitu juga penellitian yang dilakukan Milansari, Masitoh, dan Siddi (2020) yang menunjukkan bahwa current ratio berpengaruh terhadap struktur modal. Penelitian lain yang dilakukan Ramadhani dan Fitra (2019) menunjukkan bahwa rasio likuiditas berpengaruh negatif dan tidak signifikan terhadap struktur modal. Penelitian yang dilakukan Firmanullah dan Darsono (2017) juga menunjukkan bahwa likuiditas tidak berpengaruh signifikan terhadap struktur modal.

Rasio profitabilitas mengukur kemampuan perusahaan dalam menghasilkan laba dan mengukur tingkat pengembalian atas investasi yang dilakukan. Rasio profitabilitas juga mencerminkan bagaimana kinerja manajemen dalam menjaga efektivitas kegiatan operasi perusahaan (Sukamulja, 2019). Rasio profitabilitas yang digunakan dalam penelitian ini adalah return on asset (ROA) yang mengukur kemampuan perusahaan untuk menghasilkan laba bersih dari aset yang dimiliki sekaligus mengukur tingkat pengembalian atas investasi perusahaan (Sukamulja, 2019).Trade-off theory mempunyai implikasi bahwa manajer akan berfikir dalam kerangka trade-off antara penghematan pajak dan biaya kesulitan keuangan dalam penentuan struktur modal. Perusahaan-perusahaan dengan tingkat profitabilitas yang tinggi tentu akan berusaha mengurangi pajaknya dengan cara meningkatkan rasio utangnya, sehingga tambahan utang tersebut akan mengurangi pajak (Myers, 1984) dalam Sulindiawati, Yuniarta, dan Purnamawati (2020). Sedangkan pecking order theory menyatakan bahwa perusahaan dengan tingkat profitabilitas yang tinggi justru tingkat utangnya rendah dikarenakan perusahaan yang profitabilitasnya tinggi memiliki sumber dana internal yang berlimpah (Myers, 1984) dalam Sulindiawati, Yuniarta, dan Purnamawati (2020). Penelitian Soukotta dan M.Chabachib (2012) menunjukkan bahwa profitabilitas (ROA) berpengaruh negatif dan signifikan terhadap struktur modal. Penelitian Cristie dan Fuad ((2015) juga menunjukkan profitabilitas berpengaruh negatif terhadap struktur modal. Penelitian lain yang dilakukan Surjadi dan Viviana (2019) menunjukkan bahwa profitabilitas berpengaruh negatif dan tidak signifikan terhadap struktur modal.

Struktur aset merupakan perimbangan atau perbandingan antara unsur-unsur yang terdapat di dalam aset, yakni aset lancar dan aset tetap. Aset merupakan modal operasi perusahaan yang didanai oleh modal asing dan modal sendiri sehingga total aset sama besar dengan total utang dan modal sendiri (Irfani, 2020). Perusahaan yang mempunyai aset tinggi cenderung akan lebih mudah mendapatkan hutang dibandingkan dengan perusahaan yang mempunyai aset yang kecil karena dengan aset yang tinggi dapat dijadikan jaminan dalam membayar utang perusahaan (Milansari, Masitoh, dan Siddi, 2020). Perusahaan yang memiliki aktiva yang digunakan sebagai agunan utang cenderung menggunakan utang yang relative lebih besar (Sulindiawati, Yuniarta, dan Purnamawati, 2020). Penelitian Jusrizal dan Aloysius H (2017) menunjukkan struktur aset berpengaruh signifikan negatif terhadap struktur modal. Penelitian Kennedy, Azlina dan Suzana (2011) menunjukkan struktur aktiva secara signifkan berpengaruh terhadap struktur modal. Penelitian lain yang dilakukan Nurrohim KP (2008) menunjukkan bahwa struktur aset tidak berpengaruh signifikan terhadap struktur modal. 


\section{KAJIAN TEORI}

\section{Struktur Modal}

Teori yang terkait dengan struktur modal antara lain trade-off theory yang diungkapkan oleh Myers (2001) dalam Sulindawati, Yuniarta, dan Purnamawati (2020) bahwa perusahaan akan berutang sampai pada tingkat utang tertentu, dimana penghematan pajak (tax shields) dari tambahan utang sama dengan biaya kesulitan keuangan (financial distress). Biaya kesulitan keuangan (financial distress) adalah biaya kebangkrutan (bankcruptcy costs) atau reorganization, dan biaya keagenan (agency cost) yang meningkat akibat dari turunnya kredibilitas suatu perusahaan. Trade-off theory dalam menentukan struktur modal yang optimal memasukkan beberapa faktor antara lain pajak, biaya keagenan, dan biaya kesulitan keuangan tetapi tetap mempertahankan asumsi efisiensi pasar dan symmetric information sebagai imbangan dan manfaat penggunaan utang. Tingkat utang yang optimal tercapai ketika penghematan pajak mencapai jumlah yang maksimal terhadap biaya kesulitan keuangan. Tradeoff theory mempunyai implikasi bahwa manajer akan berpikir dalam kerangka trade-off antara penghematan pajak dan biaya kesulitan keuangan dalam penentuan struktur modal. Perusahaanperusahaan dengan tingkat profitabilitas yang tinggi tentu akan berusaha mengurangi pajaknya dengan cara meningkatkan rasio utangnya, sehingga tambahan utang tersebut akan mengurangi pajak.

Teori lain terkait struktur modal yaitu pecking order theory, menurut Myers (1984) dalam Sulindawati, Yuniarta, dan Purnamawati (2020) menyatakan bahwa perusahaan dengan tingkat profitabilitas yang tinggi justru tingkat utangnya rendah, dikarenakan perusahaan yang profitabilitasnya tinggi memiliki sumber dana internal yang berlimpah. Dalam pecking order theory ini tidak terdapat struktur modal yang optimal. Secara spesifik perusahaan mempunyai urut-urutan preferensi (hierarki) dalam penggunaan dana. Struktur modal adalah perimbangan atau perbandingan antara modal asing dan modal sendiri. Modal asing diartikan dalam hal ini adalah utang baik jangka panjang maupun dalam jangka pendek. Sedangkan modal sendiri bisa terbagi atas laba ditahan dan bisa juga dengan penyertaan kepemilikan perusahaan (Sulindawati, Yuniarta, dan Purnamawati, 2020). Struktur modal merupakan perimbangan antara jumlah hutang jangka pendek bersifat permanen, hutang jangka panjang, saham preferen dan saham biasa. Struktur modal adalah perbandingan antara modal asing atau jumlah hutang dengan modal sendiri (Musthafa, 2017). Variabel yang digunakan untuk mengukur struktur modal adalah Debt To Equity Ratio (DER), rasio ini dihitung sebagai hasil bagi antara total utang dengan modal. Rasio ini berfungsi untuk mengetahui berapa bagian dari setiap modal rupiah yang dijadikan sebagai jaminan utang (Hery, 2015).

Debt To Equity Ratio $(\mathrm{DER})=\frac{\text { Total Utang }}{\text { Modal }}$

\section{Likuiditas}

Rasio likuiditas adalah rasio yang menunjukkan kemampuan perusahaan dalam memenuhi kewajiban atau membayar utang jangka pendeknya. Dengan kata lain, rasio likuiditas adalah rasio yang dapat digunakan untuk mengukur sampai seberapa jauh tingkat kemampuan perusahaan dalam melunasi kewajiban jangka pendeknya yang akan segera jatuh tempo. Jika perusahaan memiliki kemampuan untuk melunasi kewajiban jangka pendeknya pada saat jatuh tempo, maka perusahaan tersebut dikatakan sebagai perusahaan yang likuid. Sebaliknya jika perusahaan tidak memiliki kemampuan untuk melunasi kewajiban jangka pendeknya pada saat 
jatuh tempo, maka perusahaan tersebut dikatakan sebagai perusahaan yang tidak likuid (Hery, 2015). Rasio likuiditas yang digunakan adalah rasio lancar atau current ratio (CR) yang merupakan rasio untuk mengukur kemampuan perusahaan dalam memenuhi kewajiban jangka pendeknya yang segera jatuh tempo dengan menggunakan aset lancar yang tersedia.Current Ratio dihitung sebagai hasil bagi antara total aset lancar dengan total kewajiban lancar (Hery, 2015).

Current Ratio $(\mathrm{CR})=\quad \frac{\text { Aset Lancar }}{\text { Kewajiban Lancar }}$

\section{Profitabilitas}

Rasio profitabilitas merupakan rasio yang menggambarkan kemampuan perusahaan dalam menghasilkan laba melalui semua kemampuan dan sumber daya yang dimilikinya, yaitu berasal dari kegiatan penjualan, penggunaan aset, maupun penggunaan modal. Rasio profitabilitas dapat digunakan sebagai alat untuk mengukur tingkat efektivitas kinerja manajemen. Kinerja yang baik akan ditunjukkan lewat keberhasilan manajemen dalam menghasilkan laba yang maksimal bagi perusahaan. Rasio keuangan yang sering digunakan untuk menilai profitabiitas perusahaan secara keseluruhan adalah return on assets (ROA). Return on assets merupakan rasio yang menunjukkan hasil (return) atas penggunaan aset perusahaan dalam menciptakan laba bersih. ROA dihitung dengan cara membagi laba bersih dengan total aset. Semakin tinggi hasil pengembalian atas aset berarti semakin tinggi pula jumlah laba bersih yang dihasilkan dari setiap rupiah dana yang tertanam dalam total aset. Sebaliknya semakin rendah hasil pengembalian atas aset berarti semakin rendah pula jumlah laba bersih yang dihasilkan dari setiap rupiah dana yang tertanam dalam total aset (Hery, 2015).

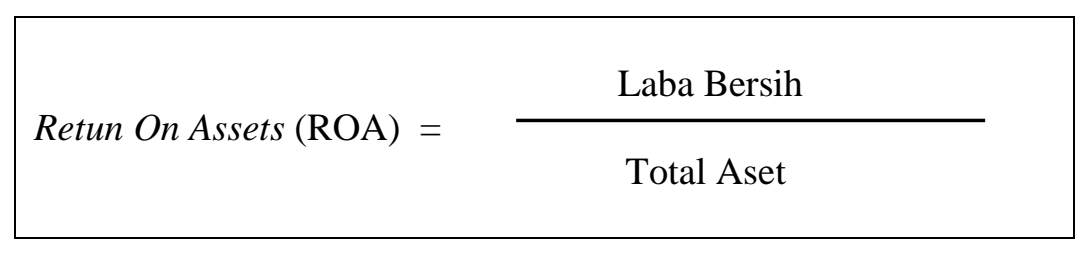

\section{Struktur Aset}

Menurut Brigham dan Houston (2011) dalam Milansari, Masitoh, dan Siddi (2020), Struktur aset adalah perimbangan atau perbandingan antara aset tetap dan total aset. Perusahaan yang mempunyai aset tinggi cenderung akan lebih mudah mendapatkan hutang dibandingkan dengan perusahaan yang mempunyai aset yang kecil karena dengan aset yang tinggi dapat dijadikan jaminan dalam membayar hutang perusahaan. Struktur aktiva menggambarkan sebagian jumlah aset yang dapat dijadikan jaminan (collateral value of assets) (Soukotta dan M.Chabachib, 2012).

Struktur Aset $=\frac{\text { Aset Tetap }}{\text { Total Aset }}$




\section{Kerangka Berfikir}

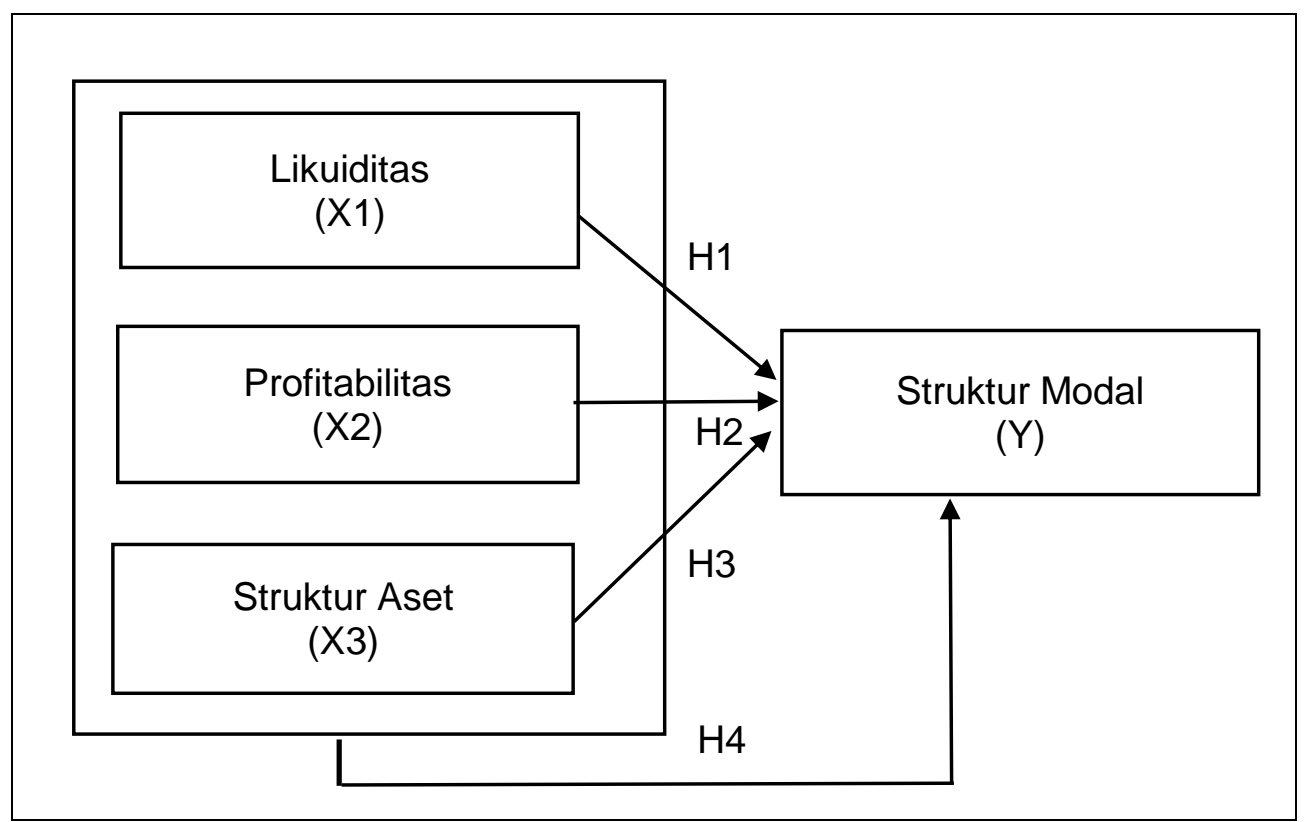

Gambar 1. Kerangka Berfikir

\section{Hipotesis Penelitian:}

Berdasarkan kerangka berfikir di atas, hipotesis dalam penelitian ini sebagai berikut:

$\mathrm{H}_{1}$ : Likuiditas berpengaruh signifikan terhadap Struktur Modal.

$\mathrm{H}_{2}$ : Profitabilitas berpengaruh signifikan terhadap Struktur Modal.

$\mathrm{H}_{3}$ : Struktur Aset berpengaruh signifikan terhadap Struktur Modal.

$\mathrm{H}_{4}$ : Likuiditas, Profitabilitas, dan Struktur Aset secara simultan berpengaruh signifikan terhadap Struktur Modal.

\section{METODE PENELITIAN}

\section{Teknik Analisis Data}

\section{Uji Asumsi Klasik}

a. Uji Normalitas

Persamaan regresi dikatakan baik jika mempunyai data variabel terikat berdistribusi mendekati normal atau normal sama sekali. Uji normalitas pada penelitian ini menggunakan uji statistik non-parametrik Kolmogorof-Smirnov (K-S). Uji K-S dilakukan dengan membuat hipotesis (Ghozali, 2011):

H0: Data Residual berdistribusi normal

HA: Data Residual tidak berdistribusi normal

\section{b. Uji Multikoloniearitas}

Model regresi yang baik seharusnya tidak terjadi korelasi di antara variabel independen. Multikolonieritas dapat dilihat dari (1) nilai Tolerance dan lawannya (2) Variance Inflation Factor (VIF). Tolerance mengukur variabilitas variabel independen yang terpilih yang tidak dijelaskan oleh variabel independen lainnya. Jadi nilai tolerance yang rendah sama dengan nilai VIF yang tinggi (karena VIF $=1$ /Tolerance). Nilai cutoff yang umum dipakai untuk 
menunjukkan adanya multikolonieritas nilai Tolerance $\leq 0,1$ atau sama dengan niai VIF $\geq 10$ (Ghozali, 2011).

\section{c. Uji Heterokedastisitas}

Heteroskedastisitas berarti ada varian variabel pada model regresi yang tidak sama (konstan). Uji heteroskedastisitas dengan metode Glesjer dilakukan dengan meregresikan semua variabel bebas terhadap nilai mutlak residualnya. Jika nilai probabilitas lebih besar dari nilai alpha (Sig. $>\alpha$ ), maka dapat dipastikan model tidak mengandung gejala heteroskedastisitas (Suliyanto, 2011).

\section{d. Uji Autokorelasi}

Uji korelasi bertujuan untuk mengetahui apakah ada korelasi antara anggota serangkaian data observasi yang diuraikan menurut times series atau cross section. Uji autokorelasi dengan metode Run Test untuk menguji apakah antar residual terdapat korelasi yang tinggi. Untuk menyimpulkan apakah terjadi gejala autokorelasi atau tidak maka maka nilai probabilitas dibandingkan dengan nilai alphanya (Suliyanto, 2011).

\section{Analisis Regresi Berganda}

Pada model regresi berganda variabel tergantung dipengaruhi oleh dua atau lebih variabel bebas sehingga hubungan fungsional antara variabel tergantung (Y) dengan variabel bebas (X) ditulis dalam persamaan (Suliyanto, 2011):

$$
\mathrm{Y}=\mathrm{a}+\mathrm{b}_{1} \mathrm{X}_{1}+\mathrm{b}_{2} \mathrm{X}_{2}+\ldots+\mathrm{b}_{\mathrm{n}} \mathrm{X}_{\mathrm{n}}+\mathrm{e}
$$

\section{Uji Signifikansi Parameter Individual (Uji Statistik t)}

Uji statistik t menunjukkan seberapa jauh pengaruh satu variabel penjelas/independen secara individual dalam menerangkan variasi variabel dependen/ terikat (Ghozali, 2011). Pengujian ini dilakukan untuk menentukan signifikan atau tidak signifikan masing-masing nilai koefisien regresi secara sendiri-sendiri terhadap variabel terikat (Sunyoto, 2016).

\section{Uji Signifikansi Simultan ( Uji Statistik F)}

Uji statistik F menunjukkan apakah semua variabel independen atau bebas yang dimasukkan dalam model mempunyai pengaruh bersama-sama terhadap variabel dependen/terikat (Ghozali, 2011). Pengujian secara simultan menggunakan distribusi F yaitu membandingkan antara F hitung dengan F tabel (Sunyoto, 2016).

\section{Koefisien Determinasi}

Koesien determinasi $\left(\mathrm{R}^{2}\right)$ mengukur seberapa jauh kemampuan model dalam menerangkan variasi variabel independen. Nilai koefisien determinasi adalah nol dan satu. Nilai $R^{2}$ yang kecil berarti kemampuan variabel-variabel independen dalam menjelaskan variasi variabel dependen amat terbatas. Nilai mendekati satu berarti variabel-variabel independen memberikan hampir semua informasi yang dibutuhkan untuk memprediksi variasi variabel dependen (Ghozali, 2011).

\section{Populasi dan Sampel}

Populasi yang digunakan pada penelitian ini adalah perusahaan sub sektor Farmasi yang terdaftar di Bursa Efek Indonesia periode tahun 2015-2019. Untuk mendapatkan sampel yang sesuai dengan tujuan penelitian ini maka sampel yang dipilih menggunakan metode purposive sampling dengan beberapa kriteria tertentu. Kriteria yang digunakan adalah perusahaan yang terdaftar secara konsisten pada periode tahun 2015-2019, perusahaan yang mengalami posisi laba secara terus menerus pada periode tahun 2015-2019, perusahaan yang memiliki ketersediaan dan kelengkapan data selama periode 2015-2019. Berdasarkan kriteria tersebut 
maka dipilih 7 perusahaan sub sektor farmasi yang terdaftar di Bursa Efek Indonesia selama 5 tahun pada periode tahun 2015-2019.

\section{HASIL PENELITIAN DAN PEMBAHASAN}

\section{Hasil Penelitian \\ Uji Normalitas}

Tabel 1. Uji Normalitas

One-Sample Kolmogorov-Smirnov Test

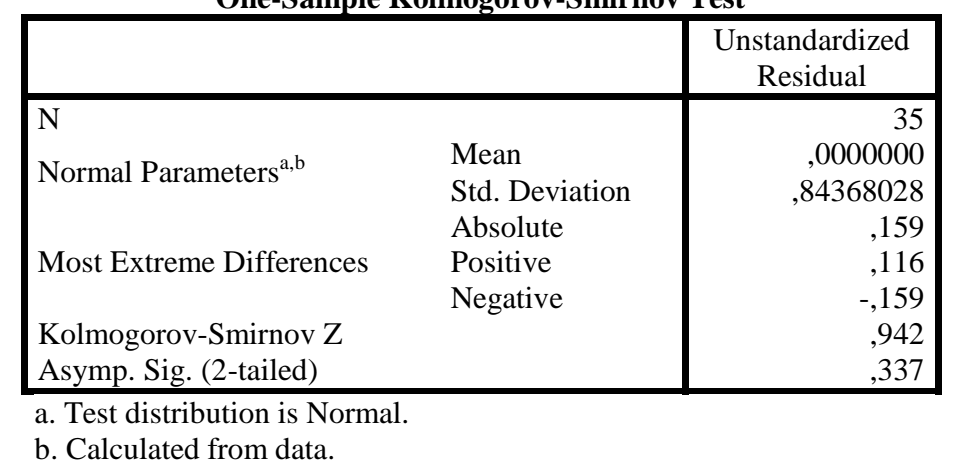

Sumber: Data Diolah

Berdasarkan output dengan uji statistik non-parametrik Kolmogorof-Smirnov (K-S) diperoleh nilai Sig. (2-tailed) sebesar 0,337 lebih besar dari 0,05 (0,337>0,05). Oleh sebab itu, Ho tidak dapat ditolak, sehingga dapat disimpulkan bahwa data residual terdistribusi normal.

\section{Uji Multikolonieritas}

\section{Tabel 2. Uji Multikolonieritas}

Coefficients $^{\mathrm{a}}$

\begin{tabular}{|rl|r|r|r|r|r|}
\hline \multirow{2}{*}{ Model } & \multicolumn{2}{|c|}{ Unstandardized Coefficients } & \multicolumn{1}{c|}{$\begin{array}{c}\text { Standardized } \\
\text { Coefficients }\end{array}$} & \multicolumn{2}{c|}{ Collinearity Statistics } \\
\cline { 3 - 7 } & & \multicolumn{1}{c|}{ B } & Std. Error & \multicolumn{1}{c|}{ Beta } & Tolerance & \multicolumn{1}{c|}{ VIF } \\
\hline \multirow{2}{*}{1} & (Constant) & $-4,960$ & 1,229 & & & \\
& Likuiditas &,- 403 &, 248 &,- 241 &, 710 & 1,409 \\
& Profitabilitas & $-1,135$ &, 311 &,- 564 &, 651 & 1,536 \\
& Struktur_Aset & $-1,204$ &, 497 &,- 323 &, 877 & 1,140 \\
\hline
\end{tabular}

a. Dependent Variable: Struktur_Modal

\section{Sumber: Data Diolah}

Berdasarkan output terlihat bahwa nilai TOL (Tolerance) variabel Likuiditas sebesar 0,710, variabel Profitabilitas sebesar 0,651, dan variabel Struktur Aset sebesar 0,877. Nilai VIF (Variance Infloating Factor ) untuk variabel Likuiditas sebesar 1,409, variabel Profitabilitas sebesar 1,536, dan variabel Struktur Aset sebesar 1,140. Nilai TOL untuk variabel Likuiditas, Profitabilitas, dan Struktur aset bernilai lebih dari 0,01. Nilai VIF untuk variabel Likuiditas, Profitabilitas, dan Struktur aset bernilai kurang dari 10. Maka dapat disimpulkan bahwa pada model regresi yang terbentuk tidak terjadi gejala multikolonieritas. 


\section{Uji Heteroskedastisitas}

\section{Tabel 3. Uji Heteroskedastisitas}

Coefficients $^{\mathrm{a}}$

\begin{tabular}{|rl|r|r|r|r|r|}
\hline Model & \multicolumn{2}{|c|}{ Unstandardized Coefficients } & \multicolumn{2}{c|}{$\begin{array}{c}\text { Standardized } \\
\text { Coefficients }\end{array}$} & \multirow{2}{*}{ Sig. } \\
\cline { 3 - 5 } & & \multicolumn{1}{|c|}{ B } & Std. Error & \multicolumn{2}{c|}{ Beta } & \\
\hline \multirow{2}{*}{1} & (Constant) &, 348 &, 117 & & 2,969 &, 006 \\
& Likuiditas &,- 025 &, 019 &,- 288 & $-1,340$ &, 190 \\
& Profitabilitas &,- 121 &, 649 &,- 041 &,- 187 &, 853 \\
& Struktur_Aset &,- 162 &, 278 &,- 103 &,- 584 &, 564 \\
\hline
\end{tabular}

a. Dependent Variable: Abs_RES

\section{Sumber: Data Diolah}

Berdasarkan output di atas diketahui nilai signifikansi (sig) untuk variabel Likuiditas sebesar 0,190, variabel Profitabilitas sebesar 0,853, dan variabel Struktur Aset sebesar 0,564. Nilai signifikansi untuk variabel Likuiditas, Profitabilitas, dan Struktur aset bernilai lebih besar dari 0,05 maka dapat disimpulkan bahwa dalam model regresi tidak terjadi gejala heterokedastisitas.

\section{Uji Autokorelasi}

Tabel 4. Uji Autokorelasi Runs Test

\begin{tabular}{|c|c|}
\hline & $\begin{array}{c}\text { Unstandardized } \\
\text { Residual }\end{array}$ \\
\hline $\begin{array}{l}\text { Test Value } \\
\text { Cases < Test Value } \\
\text { Cases >= Test Value } \\
\text { Total Cases } \\
\text { Number of Runs } \\
\text { Z } \\
\text { Asymp. Sig. (2-tailed) }\end{array}$ & $\begin{array}{r}, 17581 \\
17 \\
18 \\
35 \\
13 \\
-1,712 \\
, 087\end{array}$ \\
\hline
\end{tabular}

Sumber: Data Diolah

Pada output Run Test di atas terlihat bahwa nilai probabilitas sebesar 0,087 lebih besar dari 0,05 $(0,087>0,05)$ sehingga hipotesis nihil menyatakan nilai residual menyebar secara acak diterima. Maka dapat disimpulkan tidak terdapat gejala autokorelasi dalam persamaan regresi tersebut.

\section{Analisis Regresi Beganda}

Tabel 5. Analisis Regresi Berganda

$$
\text { Coefficients }^{\mathrm{a}}
$$

\begin{tabular}{|rl|r|r|r|r|r|}
\hline Model & \multicolumn{2}{|c|}{ Unstandardized Coefficients } & \multicolumn{1}{c|}{$\begin{array}{c}\text { Standardized } \\
\text { Coefficients }\end{array}$} & \multirow{2}{*}{ Sig. } \\
\cline { 3 - 5 } & & \multicolumn{1}{|c|}{ B } & Std. Error & Beta & \\
\hline \multirow{2}{*}{1} & (Constant) & $-4,960$ & 1,229 & & $-4,037$ &, 000 \\
& Likuiditas &,- 403 &, 248 &,- 241 & $-1,624$ &, 114 \\
& Profitabilitas & $-1,135$ &, 311 &,- 564 & $-3,645$ &, 001 \\
& Struktur_Aset & $-1,204$ &, 497 &,- 323 & $-2,421$ &, 022 \\
\hline
\end{tabular}

a. Dependent Variable: Struktur_Modal

Sumber: Data Diolah 
Berdasarkan output di atas, persamaan regresi linier berganda yang terbentu adalah sebagai berikut:

$\mathrm{Y}=-4,960-0,403 \mathrm{X}_{1}-1.135 \mathrm{X}_{2}-1,204 \mathrm{X}_{3}$

Dalam hal ini:

$\mathrm{Y}=$ Strukur Modal

$\mathrm{X}_{1}=$ Likuiditas

$\mathrm{X}_{2}=$ Profitabilitas

$\mathrm{X}_{3}=$ Struktur Aset

Dari persamaan regresi di atas dapat diartikan:

1. Nilai constant sebesar $-4,960$, jika variabel independen bernilai nol maka Struktur Modal bernilai $-4,960$.

2. Koefisien regresi $X_{1}$ menunjukan angka $-0,403$, menyatajkan bahwa jika variabel Likuiditas naik sebesar 1 satuan, variabel Profitabilitas dan variabel Struktur Aset bernilai tetap maka variabel Struktur Modal akan turun sebesar 0,403.

3. Koefisien regresi $X_{2}$ menunjukan angka $-1,135$, menyatakan bahwa jika variabel Profitabilitas naik sebesar 1 satuan, variabel Likuiditas dan variabel Struktur Aset bernilai tetap maka Struktur Modal akan turun sebesar 1,135.

4. Koefisien regresi $X_{3}$ menunjukan angka -1,204, menyatakan bahwa jika variabel Struktur Aset naik sebesar 1 satuan, variabel Likuiditas dan variabel Profitabilitas bernilai tetap maka Struktur Modal akan turun sebesar 1,204.

\section{Uji Signifikansi Parameter Individual (Uji Statistik t)}

Tabel 6. Uji Signifikansi Parameter Individual Coefficients $^{\mathrm{a}}$

\begin{tabular}{|c|c|c|c|c|c|c|}
\hline \multirow[t]{2}{*}{ Mod } & & \multicolumn{2}{|c|}{ Unstandardized Coefficients } & \multirow{2}{*}{$\begin{array}{c}\text { Standardized } \\
\text { Coefficients } \\
\text { Beta }\end{array}$} & \multirow[t]{2}{*}{$\mathrm{T}$} & \multirow[t]{2}{*}{ Sig. } \\
\hline & & $\mathrm{B}$ & Std. Error & & & \\
\hline \multirow{4}{*}{1} & (Constant) & $-4,960$ & 1,229 & & $-4,037$ &, 000 \\
\hline & Likuiditas &,- 403 & ,248 &,- 241 & $-1,624$ &, 114 \\
\hline & Profitabilitas & $-1,135$ & ,311 &,- 564 & $-3,645$ & 001 \\
\hline & Struktur_Aset & $-1,204$ & ,497 &,- 323 & $-2,421$ & 022 \\
\hline
\end{tabular}

a. Dependent Variable: Struktur_Modal

Sumber: Data Diolah

Uji parsial untuk variabel Likuiditas diperoleh nilai Sig. sebesar 0,114 lebih besar dari 0,05 $(0,114>0,05)$ dan nilai $t$ hitung sebesar $-1,624$ lebih besar dari nilai t tabel sebesar $-2,040$ (1,624>-2,040), maka $\mathrm{H}_{0}$ diterima dan $\mathrm{H}_{1}$ ditolak sehingga Likuiditas tidak berpengaruh signifikan terhadap Struktur Modal. Uji parsial untuk variabel Profitabilitas diperoleh nilai Sig. sebesar 0,001 lebih kecil dari $0,05(0,001<0,05)$ dan nilai thitung sebesar $-3,645$ lebih kecil dari nilai $\mathrm{t}$ tabel sebesar $-2,040(-3,645<-2,040)$, maka $\mathrm{H}_{0}$ ditolak dan $\mathrm{H}_{2}$ diterima sehingga Profitabilitas berpengaruh signifikan terhadap Struktur Modal. Uji parsial untuk variabel Struktur Aset diperoleh nilai Sig. sebesar 0,022 lebih kecil dari $0,05(0,022<0,05)$ dan nilai $t$ hitung sebesar $-2,421$ lebih kecil dari nilai t tabel sebesar $-2,040 \quad(-2,421<2,040)$, maka $\mathrm{H}_{0}$ ditolak dan $\mathrm{H}_{3}$ diterima sehingga Struktur Aset berpengaruh signifikan terhadap Struktur Modal. 


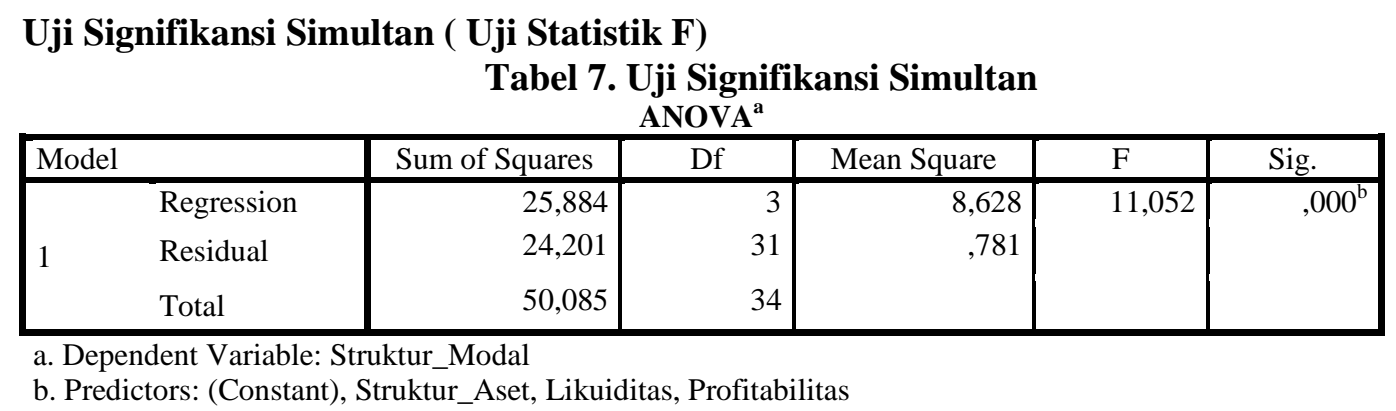

Sumber: Data Diolah

Berdasarkan uji simultan (uji F) diperoleh nilai Sig. sebesar 0,000 lebih kecil dari 0,05 dan nilai F hitung sebesar 11,052 lebih besar dari nilai $\mathrm{F}$ tabel sebesar 2,911 maka $\mathrm{H}_{0}$ ditolak dan $\mathrm{H}_{4}$ diterima sehingga secara simultan Likuiditas, Profitabilitas, dan Struktur Aset berpengaruh signifikan terhadap Struktur Modal.

\section{Koefisien Determinasi}

\section{Tabel 8. Koefisien Determinasi}

\begin{tabular}{|l|r|r|r|r|}
\hline Model & R & R Square & $\begin{array}{c}\text { Adjusted R } \\
\text { Square }\end{array}$ & $\begin{array}{c}\text { Std. Error of the } \\
\text { Estimate }\end{array}$ \\
\hline 1 &, $719^{\mathrm{a}}$ &, 517 &, 470 &, 88356 \\
\hline
\end{tabular}
a. Predictors: (Constant), Struktur_Aset, Likuiditas, Profitabilitas
b. Dependent Variable: Struktur_Modal

Berdasarkan uji koefisien determinasi diperoleh angka R Square sebesar 0,517 atau 51,7\%, yang berarti bahwa variabel Likuiditas, Profitabilitas, dan Struktur Aset memberikan pengaruh sebesar 51,7\% terhadap Struktur Modal dan sebesar 48,3\% dipengaruhi variabel lain yang tidak ada dalam penelitian ini.

\section{Pembahasan Hasil Penelitian}

\section{Pengaruh Likuiditas Terhadap Struktur Modal}

Uji parsial untuk variabel Likuiditas diperoleh nilai Sig. sebesar 0,114 lebih besar dari 0,05 $(0,114>0,05)$ dan nilai t hitung sebesar $-1,624$ lebih besar dari nilai t tabel sebesar -2,040 (1,624>-2,040), maka $\mathrm{H}_{0}$ diterima dan $\mathrm{H}_{1}$ ditolak sehingga likuiditas tidak berpengaruh signifikan terhadap struktur modal. Dapat diartikan bahwa tinggi rendahnya likuiditas tidak memberikan pengaruh terhadap struktur modal perusahaan. Apabila rasio lancar rendah dapat dikatakan perusahaan kurang modal untuk membayar utang, namun apabila pengukuran rasio lancar tinggi belum tentu kondisi perusahaan sedang baik (Kasmir, 2017). Kondisi keuangan yang baik adalah tidak hanya sekedar likuid melainkan juga harus memenuhi standar likuiditas tertentu, khususnya untuk menghadapi kewajiban keuangan yang tidak terduga namun memerlukan pembayaran yang segera (Hery, 2015). Hasil penelitian ini sejalan dengan penelitian yang dilakukan oleh Firmanullah dan Darsono (2017) yang membuktikan bahwa likuiditas tidak memberikan pengaruh signifikan terhadap struktur modal. Hasil peneitian Ramadhani dan Fitra (2019) juga membuktikan bahwa current ratio tidak signifikan terhadap struktur modal.

\section{Pengaruh Profitabilitas Terhadap Struktur Modal}

Uji parsial untuk variabel Profitabilitas diperoleh nilai Sig. sebesar 0,001 lebih kecil dari 0,05 $(0,001<0,05)$ dan nilai t hitung sebesar $-3,645$ lebih kecil dari nilai t tabel sebesar $-2,040$ ($3,645<-2,040)$, maka $\mathrm{H}_{0}$ ditolak dan $\mathrm{H}_{2}$ diterima sehingga profitabilitas berpengaruh negatif dan signifikan terhadap struktur modal. Dapat diartikan bahwa semakin tinggi profitabilitas 
maka semakin rendah struktur modal perusahaan. Hasil penelitian ini sesuai dengan pecking order theory yang menyatakan bahwa perusahaan dengan tingkat profitabilitas yang tinggi justru tingkat utangnya rendah dikarenakan perusahaan yang profitabilitasnya tinggi memiliki sumber dana internal yang berlimpah (Myers, 1984) dalam Sulindawati, Yuniarta, dan Purnamawati (2020). Sehingga ketika perusahaan memilih sumber pendanaan, maka perusahaan lebih memilih untuk menggunakan sumber dana dari dalam atau pendanaan internal daripada eksternal. Hasil penelitian ini sejalan dengan penelitian Soukotta dan M.Chabachib (2012) yang menunjukkan bahwa profitabilitas (ROA) berpengaruh negatif dan signifikan terhadap struktur modal. Penelitian Cristie dan Fuad ((2015) juga menunjukkan profitabilitas berpengaruh negatif terhadap struktur modal.

\section{Pengaruh Struktur Aset Terhadap Struktur Modal}

Uji parsial untuk variabel Struktur Aset diperoleh nilai Sig. sebesar 0,022 lebih kecil dari 0,05 $(0,022<0,05)$ dan nilai t hitung sebesar $-2,421$ lebih kecil dari nilai t tabel sebesar -2,040 ($2,421<2,040)$, maka $\mathrm{H}_{0}$ ditolak dan $\mathrm{H}_{3}$ diterima sehingga struktur aset berpengaruh negatif dan signifikan terhadap struktur modal. Dapat diartikan bahwa semakin tinggi struktur aset maka semakin rendah struktur modal perusahaan. Menurut Zuliani (2014) dalam Firmanullah dan Darsono (2017), perusahaan dengan tingkat proporsi aset tetap yang besar cenderung lebih meminimalisir penggunaan utang karena dana yang dihasilkan dari aset tetap dirasa cukup untuk mendanai kegiatan operasi perusahaan, juga dana internal lebih disukai karena karena memiliki risiko lebih kecil. Hasil penelitian ini sejalan dengan penelitian Jusrizal dan Aloysius H (2017) yang menunjukkan struktur aset berpengaruh signifikan negatif terhadap struktur modal. Hasil peneitian Kennedy, Azlina, dan Suzana (2011) juga membuktikan bahwa struktur aktiva secara signifikan berpengaruh terhadap struktur modal.

\section{Pengaruh Likuiditas, Profitabilitas, dan Struktur Aset Secara Simultan Terhadap Struktur Modal}

Berdasarkan uji simultan (uji F) diperoleh nilai Sig. sebesar 0,000 lebih kecil dari 0,05 dan nilai F hitung sebesar 11,052 lebih besar dari nilai $\mathrm{F}$ tabel sebesar 2,911 maka $\mathrm{H}_{0}$ ditolak dan $\mathrm{H}_{4}$ diterima sehingga dapat diartikan bahwa secara simultan Likuiditas, Profitabilitas, dan Struktur Aset berpengaruh signifikan terhadap Struktur Modal. Berdasarkan uji koefisien determinasi diperoleh angka $\mathrm{R}$ Square sebesar 0,517 atau 51,7\%, yang berarti bahwa variabel Likuiditas, Profitabilitas, dan Struktur Aset memberikan pengaruh sebesar 51,7\% terhadap Struktur Modal dan sebesar 48,3\% dipengaruhi variabel lain yang tidak ada dalam penelitian ini.

\section{KESIMPULAN}

\section{Kesimpulan}

Kesimpulan dari penelitian ini adalah sebagai berikut:

1. Likuiditas tidak berpengaruh signifikan terhadap Struktur Modal.

2. Profitabilitas berpengaruh signifikan terhadap Struktur Modal.

3. Struktur Aset berpengaruh signifikan terhadap Struktur Modal.

4. Likuiditas, Profitabilitas, dan Struktur Aset secara simultan berpengaruh signifikan terhadap Struktur Modal.

\section{Saran}

Saran yang dapat diberikan penulis adalah sebagai berikut:

1. Bagi manajemen perusahaan, sebaiknya memperhatikan variabel profitabilitas dan struktur aset dalam pengambilan keputusan terkait struktur modal perusahaan, karena kedua variabel tersebut memberikan pengaruh yang signifikan terhadap struktur modal. 
2. Bagi peneliti selanjutnya, sebaiknya menambahkan variabel lain, menambah periode tahun penelitian, dan menggunakan objek penelitian pada klasifikasi industri yang lain dalam menganalisis struktur modal perusahaan. 


\section{DAFTAR PUSTAKA}

Cristie, Yanuar., Fuad. analisis Faktor-Faktor Yang Mempengaruhi Struktur Modal, Dengan Ukuran Perusahaan sebagai Variabel Moderating (Studi Empiris Pada Perusahaan Property And Real Estate Yang Terdaftar Di Bursa Efek Indonesia Untuk Tahun 20102013). Diponegoro Journal Of Accounting. Volume 4, Nomor 2, Halaman 1-9, ISSN (Online): 2337-3806, Tahun 2015.

Firmanullah, Nurul., Darsono. Faktor-faktor yang Mempengaruhi Struktur Modal di Perusahaan Indonesia (pada Perusahaan Manufaktur yang Terdaftar di BEI Tahun 2011-2014). Diponegoro Journal of Accounting, Volume 6, Nomor 3, Halaman 1-9, ISSN (Online): 2337-3806,Tahun 2017.

Ghozali, Imam. Aplikasi Analisis Multivariate Dengan Program IBM SPSS 19. Badan Penerbit Universitas Diponegoro. ISBN 979.704.015.1. Semarang. 2011.

Hery. Analisis Laporan Keuangan: Pendekatan Rasio Keuangan. Center for Academic Publishing Service (CAPS). ISBN 978-602-9324-61-7. Yogyakarta. 2015.

Irfani, Agus S. Manajemen Keuangan dan Bisnis: Teori dan Aplikasi. PT. Gramedia Pustaka Utama. ISBN Jakarta. 2020.

Jusrizal dan Aloysius H. Faktor-Faktor yang Mempengaruhi Struktur Modal (Studi Empiris pada Perusahaan Property dan Real Estate yang terdaftar di Bursa Efek Indonesia Tahun 2010-2014). Profita, Volume 10. No.3, 373-387, Desember 2017.

Kasmir. Analisis Laporan Keuangan. Rajawali Pers. ISBN 978-979-769-216-2. Jakarta. 2017.

Kennedy., Azlina, Nur., Suzana, Anisa Ratna. Faktor-Faktor Yang Mempengaruhi Struktur Modal Pada Perusahaan Real Estate And Property Yang Go Public Di Bursa Efek Indonesia. Jurnal Ekonomi Vol 19, No 02 (2011).

Milansari, Rani., Masitoh, Endang., Siddi, Purnama. Faktor-faktor yang Mempengaruhi Struktur Modal pada Perusahaan Makanan dan Minuman di BEI. Berkala Akuntansi dan Keuangan Indonesia, Vol.05, No.01 (2020):31-46, e-ISSN 2460-4496.

Mufidah., Ulupui,I Gusti Ketut Agung.,dan Prihatni, Rida. Pengaruh Profitabilitas, Likuiditas, dan Risiko Bisnis pada Struktur Modal Perusahaan Properti dan Real Estate di Bursa Efek Indonesia. Matrik: Jurnal Manajemen, Strategi Bisnis dan Kewirausahaan Vol.12, No.2: 129-138, Agustus 2018.

Musthafa. Manajemen Keuangan. CV Andi Offset. ISBN 978-979-29-6271-0. Yogyakarta. 2017.

Nurrohim KP, Hasa. Pengaruh Profitabilitas, Fixed Asset Ratio, Kontrol Kepemilikan dan Struktur Aktiva Terhadap Struktur Modal Pada Perusahaan Manufaktur di Indonesia. Sinergi; Kajian Bisnis Dan Manajemen Vol.10 No.1, Hal 11-18, ISSN 1410-9018, Januari 2008.

Ramadhani, Suci., Fitra, Halkadri. Pengaruh Rasio Likuiditas, Profitabilitas, dan Struktur Aktiva terhadap Struktur Modal Pada Perusahaan Telekomunikasi Indonesia yang terdaftar di BEI Periode 2010-2017. Jurnal Kajian Manajemen dan Wirausaha Volume 01 Nomor 01, 259-269, ISSN online 2655-6499, 2019.

Soukotta, Agnes dan M.Chabachib. Analisis Faktor-Faktor yang Mempengaruhi Struktur Modal (Studi Perbandingan Pada Manufacture Multinational Company dan Manufacture Domestic Corporation di Bursa Efek Indonesia. Jurnal Bisnis Strategi. Vol.21 No.1, 1-17, Juli 2012.

Sukamulja, Sukmawati. Analisis Laporan Keuangan: Sebagai Dasar Pengambilan Keputusan Investasi. Penerbit Andi. e-ISBN 978-623-01-0164-9. Yogyakarta. 2019.

Sulindawati, Ni Luh Gede Erni., Yuniarta, Gede Ardi., Purnamawati, I Gusti Ayu. Manajemen Keuangan: Sebagai Dasar Pengambilan Keputusan Bisnis. Rajawali Pers. ISBN 978-602425-179-6. Depok. 2020. 
Suliyanto. Ekonometrika Terapan: Teori dan Aplikasi dengan SPSS. CV Andi Offset. ISBN 978-979-29-2620-0. Yogyakarta. 2011.

Sunyoto, Danang. Metodologi Penelitian Akuntansi. PT Refika Aditama. ISBN 978-602-865006-8. Bandung. 2016.

Surjadi, Lukman dan Viviana. Faktor-Faktor Yang Mempengaruhi Struktur Modal Perusahaan Manufaktur Di BEI Periode 2015-2017. Jurnal Ekonomi/ Volume XXIV, No.01, 129143, March 2019.

www. idx.co.id yang diakses pada tanggal 5 Desember 2020 